Viewpoint

\title{
Limits, ecomodernism and degrowth
}

\author{
Giorgos Kallis \\ ICREA and ICTA-UAB, Autonomous University of Barcelona, Spain
}

Robbins concludes his exchange with Gómez-Baggethun by remarking that 'there is a great deal to chew here, especially with regard to the way the degrowth community attempts to thread the needle between ethical limits and Malthusian scarcity' (emphasis in the original). In explaining their positions on degrowth, both authors refer to my book on limits (Kallis, 2019). In Robbins's spirit of clarifying differences between ecomodernism and degrowth, I explain here my thesis on limits, while acknowledging that I do not speak for the degrowth community, as will become apparent from my differences with Gómez-Baggethun.

Economists in the 1970s framed the limits-to-growth question in Malthusian terms, positing scarcity against progress and giving credence to Ronald Reagan's quip that 'there are no limits to growth because there are no limits to human intelligence'. Scarcity had been the bread and butter of economists ever since Malthus invoked limits to call for growth, while rejecting redistribution (my new interpretation of his Essay - see Kallis, 2019). Many environmentalists got trapped in this economistic framing. Instead of fundamental debates over the types of worlds we want to inhabit, economists diverted discussions to technological and market fixes against scarcity, while Reagan and neoliberal policymakers worked to remove limits to growth through deregulation and the lifting of environmental protections.

For a radical environmentalism, instead, limits are not something out there that imposes scarcities but a political project towards the good and just life. 'Degrowth' does not warn of limits to growth. Rather, it expresses a desire to limit growth and open alternatives. I call this project 'collective self-limitation' and trace its origins to several sources: the Romantics, who ridiculed Malthus's premise that humans cannot limit their fertility; the anarcho-feminist Emma Goldman, an advocate of birth control; Gandhi; or the 'fundi' German Greens and the European political ecologists of the 1970s. This environmentalism, I argue, is a truly revolutionary movement: It questions not the capacity of capitalism to deliver the dream it sells, but the desirability of the dream itself.

To see the difference between Malthusian scarcity and radical degrowth, consider Goldman. Goldman was a proto-environmentalist. The cover of her magazine Mother Earth celebrated the abundance of an early Spring day-a stark contrast to the bounded Earth environmentalists depict today. She also advocated birth control in the name of free love, so that women could enjoy sexual pleasure free from the yoke of motherhood. Goldman wanted women to stop feeding expendable soldiers to imperialist war machines, and surplus labor to capitalist factories. Limiting population for Goldman was a deliberate political action- a strategy against capital and its need for limitless growth.

In my book I call upon fellow environmentalists to take ownership, like Goldman did, of our desire for limits and to abandon conservative and depoliticizing attributions of limits to an external, stingy Nature. We want to limit growth to stop the destruction of an abundant planet. We do not want growth because growth is meaningless. We are not worried that growth has limits - we worry what will happen if we do not impose limits soon enough.

Beyond political desires, it is important to acknowledge that planetary forces place limitations upon human choice. I prefer, however, the more precise term, 'thresholds' to describe external forces that precipitate or accelerate ecological changes. Gómez-Baggethun uses the terms thresholds and natural limits interchangeably. He insists that whereas scarcity is socially defined, ecological limits are physically defined, with thresholds and tipping points indicating 'natural limits'. But 'limits' is a metaphor (Norgaard, 1995) that presumes our desire for that which is limited. Gravity, for instance, is a limit if you want to jump out of the window, but not if you want to stay on your couch. Scientists can discern with more or less certainty the external thresholds of ecological changes and the consequences of current choices. Continuous growth or certain technologies may lead to exceeding such thresholds, causing disasters. What turns external geophysical forces into 'limits' is the desire to grow and supersede them. Seeing the world as an external force that imposes limits on us is an integral part of capitalism's ideology of scarcity and growth. In our culture, a politics of invoking catastrophic external limits only fuels capitalism's promise of 'more'.

The distinction between collective self-limitation, external thresholds, and scarcity offers some clarity in the debate. Ecomodernists do not deny external thresholds. They might disagree whether human adaptation to climate change breaks down at 2,3 or $4{ }^{\circ} \mathrm{C}$. But like degrowthers they seek to reduce carbon emissions. Where ecomodernists part from degrowthers is in the former's belief that limitless growth within planetary thresholds is possible (and necessary) by say developing nuclear

E-mail address: giorgoskallis@gmail.com. 
power, carbon capture or industrial genetically modified agriculture. Notice here how under capitalism the specter of limits (in this case climate change) is mobilized to justify and perpetuate more of the same: more growth, more capitalist 'technology'.

This is precisely why I emphasize collective self-limitation instead because the specter of external limits has been invoked over and again, from colonialists and Malthus in the 18th century to economists and Reaganites in the 1980s, to ecomodernists today, as a justification for limitless expansion. It is not a coincidence that earth appeared to us as a limited spaceship the moment we were flying out of it. To accept limits means to accept that there is already enough - here, on earth - but there will be enough only if we share what there is. And socialism, someone said, is about sharing.

The confusion between 'thresholds', 'limits' and 'scarcity' runs through the debate between Gómez-Baggethun and Robbins. GómezBaggethun accuses of Robbins of banalizing limits, when, in my view, Robbins's questioning of 'natural limits' actually refers to the ideology of scarcity, and not the presence of external thresholds or the need for institutionalized limits. Robbins, however, confuses the conversation by referring in same breath to 'natural limits', scarcity, and 'elitist ... forms of self-denial'. Political ecologists have indeed exposed how capitalism produces and invokes scarcity toward de-politicizing ends or to justify control over 'excess others' (Mehta, 2013). But this does not mean that planetary thresholds are irrelevant. Robbins's call for humility in the face of uncertain futures does not answer Gómez-Baggethun's concern with the material, energy and environmental implications of robots, nuclear power, GMOs, geo-engineering, and other supposed solutions to ecological destruction. Likewise, Luque-Lora in his contribution questions the political feasibility of degrowth but does not answer Gómez-Baggethun's challenge about the ecological plausibility of the technological solutions Luque-Lora seems to support.

If by self-denial Robbins means self-limitation, then Gómez-Baggethun is right also to say that there is nothing elitist or self-denying per se in calls for limits, with numerous instances of emancipatory and egalitarian struggles for limits, as seen with Gandhi's anti-colonial politics. Contra Huber, desires to 'live simply so that others may simply live' are not a Western invention of academic post-industrial workers. Lumping also all defenses of limits under the Malthusian label is analytically and politically wrong. There is a difference between reactionary prophecies of 'coming anarchy' or 'lifeboat ethics' by doomsayers like Kaplan or Hardin and struggles to limit petro-capital at Standing Rock and elsewhere. The former invoke external limits to keep others out of their lifeboats; the latter struggle politically to put limits on capital and to share lifeboats.

By missing the distinction between self-limitation and scarcity, Robbins associates limits with dystopian futures. So it is interesting to note that fictional utopias are limited worlds - islands like Homer's Ithaca or More's Utopia. Liberation and freedom, I argue in my book, require limits, like a pianist needs a finite keyboard to make music. Adventure without limit, without an Ithaca to return to, is no adventure. This classical ideal of limited worlds stands in direct contrast to the Western-frontier fiction of liberation from all limits (at the expense of the colonized 'other' of course), mythologized by Hollywood movies in which the hero beats death, the ultimate limit.

Even Robbins's socialist robotic utopia-embraced, as well, by Huber and Luque Lora- needs limits. If the dream is to liberate humans from toil, then there must be limits to what happens to liberated time. If freed time is invested to more production and consumption, like capitalism does (except when stopped by the labor movement), then we are caught in an eternal replay of Keynes's fantastical prediction that his grandchildren would work only a few hours a week. For socialism to liberate workers from work, as Huber and Luque Lora desire, limits have to be imposed so that any liberated work cannot be invested in further work to increase productivity. Workers will work less when there is a limit on work, not when robots do the work. Furthermore, if socialism treats people and environments with the value that they deserve, then this can only mean foregone economic activity compared to what capitalism could achieve. Again, this would be a conscious limit to growth.

Gómez-Baggethun revives unnecessary in his essay the caricature science wars of the 1990s. Robbins is in fact at his best when he deconstructs contested views of nature. I had expected then Robbins to tell us, in his example of the Wisconsin dairy farm, about the different views, projects, and power relations at stake in the farm's automation - and where he stands in relation. Instead, his Wisconsin ecology seems apolitical, especially given his claim to neutral observer status: he is there just to record how people adapt to forces beyond their control. Robbins says that what Gómez-Baggethun approves or disapproves is irrelevant in the face of such forces. What happened to studying the world so as to change it? Robbins's critique of the Wisconsin farm reads as a list of lamentable 'externalities' to an otherwise pastoral idyll. To borrow Robbins's (2011) own brilliant phrase: Where is all the pain hidden behind the peaceful vista?

Placing this techno-pastoral future within an unspecified 'socialism' (without elaboration of the details, possibilities, and paths of the socialist project in mind) does not make it 'political'. Technology - the robots - appears as a fix, independent of relations of production. The assumption is that a very different political order will assimilate and reproduce technologies produced under very different relations. There is a risk here of what Rob Wallace (2019) calls 'red washing capital': justifying real-existing technologies and the relations that produce them, with the excuse that in some undefined future, a hypothetical socialism (as remote a possibility as ever) could put them to good use. A socialism also that challenges capitalism's means but not its dreams does not live up to its name. How is the dream of the Wisconsin farm different from the promise capitalism has been selling to workers for centuries?

A more sympathetic reading of Robbins is that he just calls for political ecologists to hold back on their critiques of new technologies, rather than to assume they are undesirable because they are capitalintensive. Gómez-Baggethun is right, though, that Robbins (and, I would add, Luque-Lora and especially Huber) oversimplify and stereotype the degrowth position on industrial technology. To reject specific technologies does not mean that degrowthers reject all technologies, that they are oblivious to the monumental technological changes needed in the face of climate change, or that they dismiss labor-saving progress. The problem with nuclear power, for example, is not that it is 'big' or 'modern' but that a world where nuclear power supplies say half of all current energy (or worse, 10 times that by the end of the century at 3 percent annual growth) is a world with a proliferation of accidents, sabotage, and disposal risks. The concern is with the specifics and their socio-ecological implications.

The concern is also with a modernist 'fix' mentality that searches salvation in technology. Degrowth calls to pause and to reconsider a techno-system that demands freedom to discover what can be discovered (do we really need, for example, the 'gain of function' experiments that wire and store new viruses to protect us from a new pandemic, with a real risk that they might end up causing it?). The emphasis in this position is phronesis (prudence) - a democratic choice of limits.

My problem with ecomodernism is not its insistence on certain technologies (debatable as they may be), but its emphatic rejection of the need for limits. To stop climate change we need to limit some production/consumption, manage economic slowdowns and apply new technologies - from clean energy, to removing carbon to stabilizing icebergs. More, we also need to live, consume and produce differentlywith new limits and new possibilities. Ecomodernism's staunch refusal of limits is wrong and outdated. And there is nothing socialist in it.

\section{Declaration of competing interest}

No conflict of interest. 


\section{Acknowledgements}

I thank Susan Paulson, Paul Robbins and Erik Gómez-Baggethun for constructive comments and Caroline Nagel for tightening my argument. I acknowledge the financial support of the Spanish Ministry of Science, Innovation and Universities, through the "Maria de Maeztu" programme for Units of Excellence (CEX2019-000940-M).

\section{References}

Kallis, G. (2019). Limits: Why Malthus was wrong and why environmentalists should care. Stanford University Press.

Mehta, L. (2013). The limits to scarcity: Contesting the politics of allocation. Routledge. Norgaard, R. B. (1995). Metaphors we might survive by. Ecological Economics, 15(2), 129-131.

Robbins, P. (2011). Political ecology: A critical introduction (Vol. 16). John Wiley \& Sons. Wallace, R. (2019). Redwashing capital, uneven earth. https://unevenearth.org/2019/ 07/redwashing-capital/. 